\title{
Frygten for PKK dikterer Tyrkiets Syrienpolitik
}

Af Deniz Serinci

Tyrkiet frygter, at en kurdisk stat i Syrien vil påvirke tyrkiske kurderes løsrivelsestrang. PYD, som administrerer selvstyret i det nordlige Syrien, har tætte bånd til PKK. Både PKK og PYD betragter PKK's stifter Abdullah Öcalan som dets leder, og der er billeder og statuer af Öcalan overalt i det nordlige Syrien, hvor PYD har magten. Og når PKK-relaterede organisationer som PYD opretter en administration for de 2-4 mio. kurdere i Syrien, så frygter tyrkerne, at det kan inspirere de $\mathbf{1 5}$ mio. kurdere i Tyrkiet til at gøre det samme.

De fremtrædende tyrkiske redaktører Can Dündar og Erdem Gül blev i februar 2016 løsladt. De to mænd havde i flere måneder siddet fængslet, arresteret og sigtet for 'forræderi'. De havde afsløret, at den tyrkiske efterretningstjeneste $\mathrm{i}$ januar 2014 - ifølge vidneudsagn fra en anklager og domstol, som nyhedsbureauet Reuters har fået indsigt $\mathrm{i}$ - havde sendt våben til ukendte modtagere i de dele af Syrien, der er under islamistiske oprøreres kontrol. Helt præcist var der tale om seks containere med våben, camoufleret som nødhjælp Retsagen mod de to mænd startede i marts og i begyndelsen af maj blev Dündar og Gül idømt henholdsvis fem år og ti måneders fængsel og fem års fængsel.

Sagen - og den våbentransport, som de to redaktører afslørede - er yderst belastende for det regerende Retfærdigheds- og Udviklingsparti (AKP) og præsident Recep Tayyip Erdogan, da det sætter fokus på landets Syrienspolitik.

Officielt har tyrkerne taget afstand fra mange af de syriske islamistiske grupper og benægter forlydender om, at de skulle støtte dem. Der er heller ikke noget bevis for, at Tyrkiet direkte skulle have støttet den mest radikale af grupperne, nemlig Islamisk Stat (IS).

Men uofficielt er det velkendt, at tyrkiske grænsevagter fra 2012 og fremefter ofte har set den anden vej, når islamister - heriblandt fra IS - krydsede Tyrkiets 877 kilometer lange grænse til Syrien, ofte kaldt 'the jihadi highway' ind i Syrien for at kæmpe mod to af AKP's hovedfjender: Diktatoren Bashar al-Assad og Folkets Forsvarsenheder (YPG), der er den militære gren af Det Demokratiske Enhedsparti (PYD), som anses for at

Deniz Serinci er redaktør på den dansk-kurdiske netavis Jiyan.dk. 
være den syriske gren af Kurdistans Arbejderparti (PKK). Sidstnævnte har ligget $\mathrm{i}$ krig med Tyrkiet i tre årtier og figurerer på EU's terrorliste.

En FN-rapport, der blev offentliggjort i december 2014, beskrev Tyrkiet som den vigtigste rute for våben leveret til IS og al-Nusra-fronten, der er al-Qaedas lokale afdeling i Syrien. I rapporten hed det blandt andet, at "de fleste [våben]forsyninger er enten blevet beslaglagt fra de væbnede styrker i Irak, eller (i mindre grad) Den Syriske Arabiske Republik. Ellers er der primært blevet smuglet til ISIL og [al-Nusra-fronten] gennem ruter, der går igennem Tyrkiet”.

USA's efterretningschef, James Clapper, anslog, at 60 pct. af de udenlandske krigere finder vej ind til Syrien gennem Tyrkiet.

\section{Frygter PKK mere end IS}

Den tyrkiske regering afviser igen og igen beskyldningerne og henviser til, at det er vanskeligt for dem at vide, hvem der tager over grænsen til Syrien med fredeligt ærinde - såsom journalister og hvem, der gør det for at deltage i borgerkrigen.

Det er vigtigt at understrege, at Tyrkiets IS-kurs har ændret sig. Over 500 personer blev i halvåret fra januar 2015 til sommer samme år arresteret og anklaget for tilknytning til IS, og 1500 udlændinge blev udvist af Tyrkiet på grund af samme anklage.

Forholdet mellem IS og Tyrkiet blev yderligere stærkt forværret efter, at formodede IS-bombemænd den 20. juli 2015 dræbte 30 prokurdiske aktivister i byen Suruc i Sydøsttyrkiet tæt på grænsen til Syrien. Derefter gav Tyrkiet USA lov til at bruge Incirlik-luftbasen i det sydlige Tyrkiet i kampen mod den islamistiske organisation. Dermed blev det nemmere for amerikanske fly at bombe IS.

Men trods kursændringen ses stadig en tendens til, at tyrkerne først og fremmest går efter PKK - og ikke IS, sådan som det internationale samfund helst ønsker. Efter Suruc-massakren, der menes begået af IS-folk, begyndte Tyrkiet at bombe PKK-stillinger i Iraks Kurdistanregion og anholdt i de første uger efter 20. juli 1302 personer - hvoraf 847 ifølge en regeringstalsmand anklagedes for at være tilknyttet PKK, mens 137 er anklaget for at være tilknyttet IS.

Det hænger sammen med det faktum, at Tyrkiet frygter PKK mere end det frygter IS. Som pro-AKP-avisen Sabah erklærede, så er PKK og dets syriske gren PYD farligere end IS'.

Når tyrkerne i den grad frygter PYD, som administrerer selvstyret i det nordlige Syrien kendt som 'Rojava' (der betyder Vest på kurdisk), så skyldes det PYD's bånd til PKK. Selv benægter PYD, at det er en syrisk gren af PKK. Men både PKK og PYD betragter PKK's stifter Abdullah Öcalan som deres leder. Der er billeder og statuer af Öcalan overalt i det nordlige Syrien, hvor PYD har magten. Flere af krigerne i YPG, den militære gren af PYD, har tidligere kæmpet for PKK.

Det faktum, at PYD bevidst udelukker og undertrykker andre PKK-kritiske kurdiske partier, bekræfter blot tyrkerne i, at selvstyret i Rojava er en ren PKK-stat.

Havde det kurdiske selvstyre i Rojava ikke været styret af $\mathrm{PKK} / \mathrm{PYD}$, så kunne Tyrkiet måske godt leve med det. Faktisk er Tyrkiets bedste allierede i Mellemøsten i dag Kurdistans Regionale Regering (KRG), der har haft selvstyre siden 1992. 70 pct. af den tyrkisk-irakiske handel sker således mellem KRG og Tyrkiet. 
Hvis kurderne i Syrien med tiden løsriver sig fra Damaskus, hvad sker der så. Vil kurderne i Tyrkiet blive inspireret til at gøre det samme? Det er den frygt, som mange tyrkere går rundt med. Og hvis først kurderne løsriver sig fra Tyrkiet, vil andre mindretal i landet - laz'erne, tjerkesserne, grækerne, araberne, armenierne - så også løsrive sig?

Huseyin Celik, talsmand for AKP, indikerede i juni 2014, at hans land er klar til at acceptere en selvstændig kurdisk stat $\mathrm{i}$ Irak. "Hvis Irak bliver delt, og det er uundgåeligt, så er de [kurderne] vores brødre".

Men når PKK - eller PKK-relaterede organisationer som PYD - opretter en administration for de 2-4 mio. kurdere i Syrien, så frygter tyrkerne, at det kan inspirere de 15 mio. kurdere i Tyrkiet til at søge samme form for selvstændighed.

Det er allerede sket, vil mange mene: Siden sommeren 2015 har der været tiltagende kampe i Tyrkiets kurdiske områder mellem den Patriotiske Revolutionære Ungdomsbevægelse (YDG-H), en ungdomsafdeling af PKK, og de tyrkiske sikkerhedsstyrker. De sidste måneder har følgende mønster gentaget sig flere steder: Militante fra YDG-H barrikaderer bestemte byer og bydele og graver voldgrave for at forhindre ordensmagten $i$ at komme ind i området. Derefter udråber YDG-H 'selvstyre' i området - ligesom PYD har gjort i Rojava.

Derudover har PKK-folkene i Tyrkiet oprettet brigader ved navn YPS (De Civile Forsvarsenheder) tydeligt inspireret af YPG i Rojava.

\section{Tyrkiet og de syriske kurdere}

AKP behøver ikke frygte, at den kurdiske nationalisme i Irak vil påvirke kurderne i Tyrkiet. For de færreste tyrkiske kurdere føler en tilknytning til KRG og deres fæller i Irak.
Det forholder sig ganske anderledes med forholdet til de etniske fæller i Syrien, der er særdeles tæt knyttede til Tyrkiets kurdere. De syriske og tyrkiske kurdere har store ligheder i historie, dialekt og ideologi - og det er AKP meget bevidst om. Mange syriske kurdere stammer oprindeligt fra Tyrkiet og de taler den samme kurdiske kurmanji-dialekt. En tredjedel af PKK's guerillaer er syriske kurdere, og det samme er den tidligere leder af PKK's væbnede fløj, Fehman Huseyn.

PKK valgte bevidst at flytte fokus væk fra Tyrkiet til Rojava, efter at fredsprocessen mellem AKP og PKK (2013-2015) gik i stå. For organisationen frygtede, at dens popularitet - samt krigernes krigsvanthed - langsomt ville aftage, hvis den ikke holdt sig aktiv på slagmarken. Derfor sendte PKK krigerne til Rojava for at bekrige islamisterne. På den måde kunne PKK over for baglandet i Tyrkiet pege på, at man trods våbenhvilen med den tyrkiske regering stadig kæmpede og holdt sig aktiv - bare i Rojava.

Hvis kurderne i Syrien med tiden løsriver sig fra Damaskus, hvad sker der så. Vil kurderne i Tyrkiet blive inspireret til at gøre det samme? Det er den frygt, som mange tyrkere går rundt med. Og hvis først kurderne løsriver sig fra Tyrkiet, vil andre mindretal i landet - laz'erne, tjerkesserne, grækerne, araberne, armenierne - så også løsrive sig? I så fald er frygten, at Tyrkiet falder fra hinanden.

Egentlig er en sådan frygt urealistisk, hvis man skal tro meningsmålingerne. 
PKK gik oprindeligt ind for et selvstændigt Kurdistan, men droppede senere den idé til fordel for selvstyre inden for Tyrkiets grænser. PKK indså, at en selvstændig stat er urealistisk i Tyrkiet, idet mange - måske op til halvdelen - af kurderne bor i Vesttyrkiet og ikke længere i den østlige del af landet.

Mange af disse kurdere i Vesttyrkiet $ø n s k e r$ ikke at droppe deres familie og de velbetalte jobs for at rejse til det ludfattige og urolige Østtyrkiet i tilfælde af et selvstændigt Kurdistan.

Meningsmålinger viser, at kun ca. 15 pct. af kurderne i Tyrkiet bakker op om en selvstændig stat - i en måling fra 2013 afviste 77 pct. af kurderne uafhængighed. Flertallet ønsker i stedet flere kulturelle rettigheder inden for Tyrkiets grænser. Disse tal forhindrer dog ikke tyrkerne i at opretholde et skræmmescenarium om kurdisk selvstændighedstrang. For meningsmålinger viser samtidig, at et flertal af etniske tyrkere er overbeviste om, at kurderne pønser på reel løsrivelse.

Begivenheder i Rojava i maj 2015 bidrog yderligere til den tyrkiske frygt: Egentlig havde PYD tre fysisk adskilte enklaver i Rojava, nemlig Cezîre, Kobanê og Efrîn. I maj 2015 lykkedes det så YPG at erobre byen imellem Cezîre og Kobanê, nemlig Tel Abyad/Girê Sipî. Dermed kunne PYD/PKK bedre forbinde de kurdiske områder med hinanden og var dermed kommet et skridt nærmere drømmen om en sammenhængende enhed i Rojava - et syrisk Kurdistan.

Det gjorde, at den tyrkiske AKP-regering igen luftede ideen om at oprette en flyveforbudszone i Syrien, der skal strække sig cirka $90 \mathrm{~km}$ langs den tyrkisk-syriske grænse og række 40-55 km ind i Syrien.
Formålet med sådan en zone er reelt fra tyrkisk side at bremse PKK/PYD's fremmarch i Rojava og drive en kile ind mellem Efrîn mod vest og Kobanê og Cezîre mod øst og dermed forhindre oprettelsen af en sammenhængende PKK-stat i Rojava.

Efter erobringen af Tel Abyad sagde Tyrkiets præsident Erdogan straks, at han "aldrig vil tillade etableringen af en ny stat syd for grænsen, i Nordsyrien". Her henviser tyrkerne til, at de ikke ville føler sig trygge ved at skulle være nabo til deres egen hovedfjende gennem tre årtier, nemlig PKK - eller en syrisk afdeling af den - lige syd for grænsen, hvorfra de kan angribe Tyrkiet.

Da jeg fornylig besøgte Tyrkiet, sagde en taxachauffør det således: "Var USA glad for at have et kommunistisk Cuba i dets baghave? Var Israel glad for at have Fatah og senere Hizbollah som nabo i Sydlibanon?"

\section{Ikke en legitim leder}

Tyrkiets Syrienpolitik handler ikke kun om PKK. Det handler også om, at tyrkerne i det hele taget ikke anser præsident Bashar al-Assad som en legitim leder. $\mathrm{Da}$ den nuværende præsidents far, $\mathrm{Hafez}$ al-Assad, døde i 2000, havde naboen mod nord håbet på, at efterfølgeren, den kun 34-årige øjenlæge Bashar, ville indføre gradvise reformer.

Erdogan opfordrede rent faktisk det syriske styre til at gennemføre demokratiske reformer 'før det er for sent'. Det skete ikke, og det syriske oprør brød ud i marts 2011, påvirket af revolterne i Tunesien, Egypten, Libyen, osv. Tyrkiet begyndte herefter at give husly til den syriske opposition og Den Frie Syriske Hær. 
Tyrkiets interesse heri var og er, at Erdogan gerne ser, at Syriens flertal på næsten 75 pct. sunni-muslimer - samme retning inden for islam, som Erdogan og et flertal af tyrkerne tilhører - får del i magten.

Som det er nu, ligger næsten hele magten hos Assad-familien, der tilhører Alawi-sekten, der tæller omkring 12 pct. af befolkningen, og som er en gren inden for shia-islam. Alawitterne får størstedelen af goderne og sidder tungt på magtapparatet, hæren og efterretningstjenesten, ligesom de ofte nyder forrang i uddannelsessystemet og i forretningsverden.

Mange konservative muslimer, og Erdogan og AKP har deres baggrund i den konservative politiske islam, anser generelt alawitterne som vantro og uislamiske, fordi sekten helligholder profeten Muhammeds fætter Ali, hvilket er i strid med islams monoteisme.

Alawitterne adskiller sig på mange måder teologisk fra sunni-islam, idet de lægger mindre vægt på Koranen og hverken går i moské, tager til Mekka eller beder på den muslimske måde, og forholdet mellem alawitterne og sunnimuslimerne har derfor til tider været stormfuldt.

En regering ledet af en sunni-islamisk bevægelse i Syrien kan hjælpe AKP-regeringen med at konsolidere sin indflydelse og magt i Mellemøsten og Nordafrika i de kommende år som modvægt til den mangeårige shia-rival Iran, hvis indflydelse man ønsker at begrænse.

Som med Saudi-Arabien og Qatar, handler Tyrkiets Syrienpolitik også om at reducere den shia-muslimske halvmånes magt i Mellemøsten. Betegnelsen 'shia-halvmånen' blev første gang kendt $\mathrm{i}$
2004, da Jordans kong Abdullah i et interview med Washington Post brugte termen.

For kongen betegnede den shiitiske halvmåne en zone med shiitisk dominans, der starter hos de proiranske shiamuslimer i Bahrain, fortsætter til Iran, videre til det shiitiske Irak og til Syrien og så slutter hos Libanons shiitiske Hizbollah-milits. Som seneste eksempel kan man sige, at de proiranske Houthi-oprørere i Yemen også er kommet med i shia-halvmånen.

Den iranske hjælp til Hizbollah i Libanon bliver transporteret via Syrien. Hvis Iran mister Syrien, så risikerer de også at miste Libanon. Shia-halvmånen vil dermed miste to steder, hvorved Tyrkiets iranske rivaler vil være dobbeltsvækket.

\section{Assad og PYD}

Det faktum, at Assad og PKK/PYD angiveligt arbejder sammen, bekræfter tyrkerne $i$, at de er omringet af fjender, og at de derfor må føre en offensiv politik på området.

Når PYD/PKK pludselig har kunnet få et område i Nordsyrien, som PKK ikke formåede at få på 30 år i Tyrkiet, hænger det sammen med, at Assad i slutningen af juli 2012 selv trak sine soldater, efterretningsfolk og politi ud af en række landsbyer langs den syrisk-tyrkiske grænse, hvor kurderne dominerer.

I stedet overtog PYD kontrollen med området. I de dage havde Assads regime travlt med det ulmende oprør i Damaskus, hvorfor han formentlig valgte at efterlade Nordsyrien til PKK.

Hvad var Assads formål med sådan en handel med PKK/PYD? Han forsøgte at neutralisere kurderne, der før havde været, og på den måde sikre sig, at de ikke 
tilsluttede sig oprøret imod ham. Dermed slap Assad også for at skulle bruge militære ressourcer på at holde fred og orden i Nordsyrien. Den opgave blev udliciteret til PKK/PYD: Da nogle kurdere så demonstrerede mod Assad, som i byen Amude i juni 2013, tøvede PYD’s militære gren YPG ikke med at skyde og dræbe tre anti-Assad-demonstranter, hvilket styrkede anklagerne om, at det kurdiske parti arbejdede sammen med regimet $\mathrm{i}$ Damaskus. Ved at støtte tyrkernes fjende kunne Assad også hævne sig på naboen mod nord, der støttede FSA mod Assad.

Egentligt var der ikke noget nyt i Assad'ernes støtte til PKK. Assads far, havde været allieret med PKK i over 20 år, og PKK's fængslede leder Abdullah Öcalan levede i eksil i Damaskus i to årtier.

Årsagen til Syriens historiske støtte til PKK var, at landet havde flere udeståender med Tyrkiet. Assad var imod Tyrkiets annektering i 1938 af Hatay-provinsen, der indtil da havde været syrisk. Ligeledes var Assad imod Tyrkiets vanddæmningsprojekt GAP, der angiveligt vil resultere i mindre vand fra Eufrat og Tigris, der strømmer fra Tyrkiet til Syrien.

\section{Turkmenerne}

En faktor, der også spiller en rolle i Tyrkiets Syrienpolitik, er de tyrkisktalende turkmenere i Nordsyrien. Millioner af syrere har rødder i dette folk, som tyrkerne på den anden side af grænsen identificerer sig med af historiske, kulturelle og sproglige årsager.

Da Tyrkiet nedskød et russisk fly i efteråret 2015, fordi det russiske fly havde været inde i tyrkisk luftrum i 17 sekunder, var en underliggende årsag blandt andet turkmenerne. AKP var irriteret over, at Rusland bombede Bayirbucak- regionen, hvor anti-Assad turkmenske oprørsgrupper, der er støttet af Tyrkiet, opererede. Derudover var man irriterede over, at Rusland med dets indtog i Syrienkrigen kort tiden forinden reelt havde sikret, at Assad kunne blive siddende. Sidst men ikke mindst, brød tyrkerne sig ikke om russernes samarbejde med YPG/PYD/PKK.

Ifølge AKP-regeringens talsmand, Bulent Arinc, fordriver YPG turkmenerne i de områder, som den kurdiske milits indtager. Pro-AKP avisen Sabah taler ligefrem om, at "PYD begår systematisk etnisk udrensning".

I årtier har tyrkiske politikere og medier talt om, at tyrkisktalende folkeslag blev og bliver undertrykt i fx Sovjetunionen/Rusland, Kinas Xinjiang-provins, det tidligere kommunistiske Bulgarien og Irak under Saddam Hussein. Men bortset fra i Cypern i 1974 har Tyrkiet sjældent grebet ind for at forsvare et tyrkisk mindretal uden for Tyrkiet. Alligevel fastholder det tyrkiske establishment omtalen af de undertrykte tyrkiske brødre, simpelthen fordi det appellerer til vælgernes nationalistiske bevidsthed i Tyrkiet.

Således bliver den kurdiske og russiske behandling af turkmenere brugt til at legitimere Tyrkiets politik i Syrien, om end den sjældent medfører nogen handling.

\section{Genopliv fredsprocessen}

I en tyrkisk befolkning, hvor et flertal ifølge meningsmålinger anser PKK for at være en fjende, vil de færreste kunne acceptere at få selvsamme PKK - eller en syrisk gren af den - som nabo.

Egentlig var der en fredsproces mellem PKK og AKPs regering i Tyrkiet fra 2013 
til 2015. Efter at begge parter beskyldte hinanden for ikke at have levet op til deres forpligtelser i aftalen, brød processen sammen i juli 2015.

Hvis fredsprocessen i fremtiden bliver genoptaget og munder ud i en aftale, sluttes der fred med PKK. Hvis først Tyrkiet begraver stridsøksen, vil der formentlig ikke være grund til at opretholde det fjendtlige forhold til PKK/PYD i Syrien. En fredsslutning med PKK's afdelinger i både Tyrkiet og Syrien vil være en kæmpe fordel for AKP, for så kan Assad ikke længere bruge PKK mod Tyrki- et, sådan som han og hans far har gjort det fra 1979 til 1998 og igen fra 2012 og frem.

Men selv hvis forholdet til PKK bliver forbedret, så vil et andet problem fortsat eksistere, nemlig Assad. AKP kræver, at han går af som leder af Syrien. Det har dog lange udsigter efter Ruslands indtræden i krigen, hvor den syriske regeringshær er i offensiven og regeringen formentlig kan se frem til at blive siddende, i hvert fald i dele af Syrien. 